\title{
PENGEMBANGAN MEDIA PEMBELAJARAN MENULIS TEKS NEGOSIASI BERBASIS APLIKASI PREZI PADA SISWA KELAS X SMA
}

\section{LEARNING MEDIA DEVELOPMENT OF WRITING NEGOTIATION TEXT BASED ON PREZI APPLICATIONS OF HIGH SCHOOL'S 1OTH GRADE STUDENTS}

\author{
Anna Wijayanti \\ SMA Negeri 1 Anggana \\ Pos-el: annawijayanti.aw@gmail.com
}

*) Naskah masuk: 12 Februari 2019. Penyunting: Nur Bety, S.Pd. Suntingan I: 24 April 2019. Suntingan II: 13 Mei 2019.

\begin{abstract}
Abstrak
Penelitian ini mendekripsikan pengembangan desain media pembelajaran menulis teks negosiasi berbasis prezi pada siswa kelas X SMA, pelaksanaan media pembelajaran menulis teks negosiasi berbasis prezi pada pembelajaran kelas X SMA, dan mengetahui kelayakan media pembelajaran berbasis prezi pada pembelajaran menulis teks negosiasi. Metode yang digunakan dalam penelitian ini adalah metode penelitian dan pengembangan. Pengembangan media ini dikembangkan sesuai dengan tahapan pengembangan dari model prosedural menurut Borg dan Gall. Model penelitian pengembangan ini implementasinya hanya sampai pada langkah ke tujuh, yaitu (1) analisis kebutuhan, (2) desain dan pengembangan produk, (3) validasi produk I, (4) uji kelompok kecil, (5) validasi produk II, (6) uji kelompok besar, (7) evaluasi dan desiminasi. Setelah pretest dan posttest diketahui bahwa hasil pembelajaran mengalami peningkatan sesudah menggunakan media pembelajaran, sebesar $34,4 \%$. Berdasarkan perbedaan hasil belajar tersebut, dapat disimpulkan bahwa media pembelajaran ini layak digunakan dalam proses pembelajaran.
\end{abstract}

Kata kunci: pengembangan media, teks negosiasi, Aplikasi Prezi

\begin{abstract}
This study aims to describe the design development, the implementation, and the feasibility oflearning media of text writing based on prezi negotiation on grade $X$ of senior high school students. It uses research and development method. The development of this learning media is elaborated in accordance with the development stage of the procedural model based on Borg and Gall. This development research model is conducted only until step seven, that are (1) need analysis, (2) product design and development,(3) product validation I, (4) small group test, (5) product validation II, (6) large group test, and (7) evaluation and dissemination. The pre test and post test reveal that the learning outcome is $34.4 \%$ higher after using the media. Thus, it can be concluded that the learning media is feasible to be applied in learning process.
\end{abstract}

Keywords: media development, negotiation text, Prezi application

Pengembangan Media Pembelajaran Menulis Teks Negosiasi Berbasis Aplikasi Prezi ... 


\section{PENDAHULUAN}

Pemanfaatan teknologi internet di dalam kegiatan pembelajaran berupa penggunaan media pembelajaran online berbasis teknologi dan informasi mempunyai beragam jenis. Keberagaman media yang mudah diakses tersebut jika dimanfaatkan dengan maksimal dapat membantu proses penyampaian materi dengan cara yang lebih bervariasi. Selama ini siswa masih menganggap pembelajaran menulis merupakan suatu pembelajaran yang membosankan dan sulit dilakukan. Rasa membosankan dan kesulitan yang muncul dari diri siswa tidak hanya disebabkan oleh siswa itu sendiri tetapi juga disebabkan oleh guru yang belum berhasil membuat siswa tertarik terhadap pembelajaran Bahasa Indonesia terutama pada pembelajaran menulis.

Survei yang dilakukan di SMA Negeri 1 Anggana, kenyataan di lapangan masih terdapat permasalahan dalam pembelajaran Bahasa Indonesia khususnya materi teks negosiasi. Permasalahan tersebut, antara lain pembelajaran pada pengembangan media pembelajaran menulis teks negosiasi belum pernah menggunakan media pembelajaran online berbasis aplikasi prezi, ketersediaan labolatorium komputer yang dilengkapi koneksi internet (wifi) yang dimiliki sekolah belum dimanfaatkan secara maksimal karena adanya perubahan kurikulum yang membuat pelajaran yang berkaitan dengan komputer dihapuskan, dan keterbatasan dalam pemanfaatan alat komunikasi seperti telepon genggam yang dibawa siswa belum sepenuhnya dimanfaatkan dengan baik.

Dari uraian permasalahan tersebut permasalahan dalam penelitian ini adalah bagaimana pengembangan desain media pembelajaran menulis teks negosiasi berbasis aplikasi Prezi pada siswa kelas XSMA Negeri 1 Anggana, bagaimana pelaksanaan media pembelajaran menulis teks negosiasi berbasis aplikasi Prezi pada pembelajaran kelas X SMA Negeri 1 Anggana, dan bagaimana evaluasi media pembelajaran menulis teks negosiasi berbasis aplikasi Prezi pada pembelajaran menulis teks negosiasi?

Sejalan dengan rumusan masalah, tujuan umum penelitian ini adalah lebih khusus mendeskripsikan pengembangan media pembelajaran menulis teks negosiasi berbasis aplikasi Prezi pada siswa kelas $X$ SMA Negeri 1 Anggana. Adapun tujuan khusus penelitian ini adalah mendeskripsikan pengembangan desain media pembelajaran menulis teks negosiasi berbasis aplikasi Prezi pada siswa kelas X SMA Negeri 1 Anggana, mendeskripsikan pelaksanaan media pembelajaran menulis teks negosiasi berbasis Prezi pada pembelajaran kelas $X$ SMA Negeri 1 Anggana, dan mengetahui hasil evaluasi media pembelajaran menulis teks negosiasi berbasis aplikasi Prezi pada pembelajaran menulis teks negosiasi.

Hasil penelitian ini diharapkan dapat memberikan konstribusi yang bermanfaat, baik secara teoritis maupun praktis. Secara teoretis, penelitian ini diharapkan dapat memberikan manfaat teoritis mengenai pengembangan media pembelajaran yang menarik dalam upaya meningkatkan kualitas pembelajaran teks negosiasi. Secara praktis, penelitian ini dapat memberikan variasi dalam proses pembelajaran sehingga penyajian materi tidak monoton dan dapat memotivasi siswa dalam belajar. Selain itu, penelitian ini dapat meningkatkan pemanfaatan internet sebagai alat bantu pembelajaran sehingga dapat memotivasi siswa dalam mempelajari materi teks negosiasi dan mampu meningkatkan kualitas belajar menjadi lebih baik lagi.

\section{TEORI}

\section{Media Pembelajaran}

Perkembangan ilmu pengetahuan dan teknologi semakin mendorong upaya 
dalam pembaruan dan pemanfaatan hasilhasil teknologi dalam proses belajar. Salah satu contoh dari perkembangan ilmu pengetahuan dan teknologi di bidang pendidikan adalah penemuan-penemuan di berbagai macam media pembelajaran yang berguna untuk membantu mencapai tujuan pembelajaran (Sadiman, dkk., 2003:6).

Dengan demikian, dapat disimpulkan bahwa guru, buku teks, dan lingkungan sekolah merupakan media yang dapat menjadi sumber belajar atau wahana fisik yang mengandung materi instruksional di lingkungan siswa yang dapat merangsang siswa untuk belajar.

\section{Jenis dan Klasifikasi Media Pembe- lajaran}

Jenis media yang dimanfaatkan dalam proses pembelajaran cukup beragam, mulai dari media yang sederhana atau media konvensional hingga media yang rumit atau media yang berbasis teknologi. Kusnadi dan Sutjipto (2011:73) berpendapat bahwa dilihat dari sifat atau jenisnya, media dikelompokkan menjadi tiga yaitu kelompok media yang hanya dapat didengar atau media yang mengandalkan kemampuan suara, disebut media auditif. Kelompok media yang hanya mengandalkan indera penglihatan disebut dengan media visual dan kelompok media yang dapat didengar dan dilihat disebut dengan media audio visual.

Media pembelajaran dilihat dari teknik pemakaiannya, dapat dikelompokkan menjadi dua yaitu media elektronik atau media yang hanya dapat digunakan dengan memakai bantuan alat-alat elektronik dan media non elektronik adalah media yang dapat digunakan tanpa bantuan alat-alat elektronik.

\section{Fungsi dan Manfaat Media Pembelajaran}

Dalam suatu proses belajar mengajar, terdapat dua unsur yang amat penting, yaitu metode mengajar dan media pembelajaran. Kedua aspek ini saling berkaitan erat. Pemilihan salah satu metode pembelajaran tertentu akan memengaruhi jenis media pembelajaran yang digunakan.

Levie dan Lentz (dalam Arsyad, 2015: 20) mengemukakan empat fungsi media pembelajaran khususnya media visual, yaitu fungsi atensi, afektif, kognitif, dan kompensatoris.

Meskipun demikian, dapat disimpulkan bahwa salah satu fungsi utama media pembelajaran adalah sebagai alat bantu mengajar yang turut memengaruhi iklim, kondisi, dan lingkungan belajar yang ditata dan diciptakan oleh guru.

Arsyad (2015:29-30) menyebutkan bahwa terdapat beberapa manfaat praktis dari penggunaan media pembelajaran di dalam proses belajar mengajar, yaitu media pembelajaran dapat memperjelas penyajian pesan dan informasi, meningkatkan dan mengarahkan perhatian anak, mengatasi keterbatasan indera, ruang, dan waktu, serta memberikan kesamaan pengalaman kepada siswa.

Berdasarkan beberapa manfaat media pembelajaran yang telah dikemukakan, dapat disimpulkan bahwa media pembelajaran dapat menarik perhatian siswa terhadap materi pembelajaran yang diajarkan dan proses belajar mengajar menjadi semakin mendalam, sehingga dapat meningkatkan pemahaman siswa tentang materi yang diajarkan.

\section{Teks Negosiasi}

Tim Studi Edukasi (2014:157) menyatakan bahwa teks negosiasi merupakan teks atau naskah berisi kutipan asli dari penulis terkait tawar-menawar. Teks negosiasi memuat bentuk interaksi sosial yang bertujuan untuk mencapai kesepakatan antara kedua belah pihak yang memiliki kepentingan berbeda. Namun, kepentingan tersebut 
dapat diselesaikan dengan cara bernegosiasi atau tawar-menawar agar kedua belah pihak sama-sama diuntungkan. Kedua belah pihak memiliki hak yang sama, menerima dan saling memberi.

\section{Isi dan Struktur Teks Negosiasi}

Menurut Kosasih (2014:90) struktur teks negosiasi dibedakan menjadi empat sebagai berikut.

1) Orientasi

Pembukaan atau awalan dari percakapan sebuah negosiasi. Biasanya berupa kata salam, sapa dan sebagainya.

2) Pengajuan

Di mana pihak yang ingin tahu menanyakan suatu barang atau permasalahan yang dihadapi dan lawan bicara menjawab atau memberitahu mengenai sesuatu yang ditanyakan sehingga muncullah sebuah interaksi.

3) Penawaran

Suatu puncak dari negosiasi karena terjadi proses tawar menawar pihak satu dengan pihak yang lain untuk mendapat sebuah kesepakatan yang menguntungkan satu sama lain.

4) Persetujuan

Kesepakatan atas hasil penawaran dari kedua belah pihak.

\section{Langkah-langkah Menulis Teks} Negosiasi

a) Menentukan topik

b) Mengumpulkan informasi pendukung

c) Menyusun kerangka

d) Menyusun teks negosiasi

\section{Cara Bernegosiasi}

Negosiasi dilakukan karena pihakpihak yang berkepentingan perlu membuat kesepakatan mengenai persoalan yang menuntut penyelesaian bersama. Tujuan negosiasi adalah untuk mengurangi per- bedaan posisi setiap pihak. Mereka mencari cara untuk menemukan butir-butir yang sama sehingga akhirnya kesepakatan dapat dibuat dan diterima bersama. Serangkaian tindakan dilakukan agar negosiasi berjalan lancar. Tindakan tersebut adalah (1) mengajak untuk membuat kesepakatan. (2) memberikan alasan mengapa harus ada kesepakatan (3) membandingkan beberapa pilihan, (4) memperjelas dan menguji pandangan yang dikemukakan, (5) mengevaluasi kekuatan dan komitmen bersama, dan (5) menetapkan dan menegaskan kembali tujuan negosiasi.

Selama melakukan negosiasi, hendaknya dihindari hal-hal yang dapat merugikan kedua belah pihak. Untuk itu, komunikasi dalam negosiasi dilakukan dengan cara yang santun, yaitu (1) menyesuaikan pembicaraan ke arah tujuan praktis, (2) mengakomodasi butir-butir perbedaan dari kedua belah pihak, (3) mengajukan pandangan baru dan mengabaikan pandangan yang sudah ada tanpa memalukan kedua belah pihak, (4) mengalokasikan tugas dan tanggung jawab masing-masing, dan (5) memprioritaskan dan mengelompokkan saran atau pendapat dari kedua belah pihak.

\section{Media Pembelajaran Online Berbasis Aplikasi Prezi}

Media pembelajaran terdiri atas dua unsur penting, yaitu unsur peralatan atau perangkat keras (hardware) dan unsur pesan yang dibawa (mesagge/software), Heinich (dalam Susila dan Riyana, 2008:6). Selanjutnya, Daryanto (2010:60) berpendapat bahwa kehadiran media pembelajaran berbasis teknologi dan informasi dapat membantu guru menyampaikan materi lebih detail serta membantu siswa lebih memahami isi materi yang disampaikan.

Dari pendapat para ahli di atas dapat disimpulkan bahwa hakikat dari media pembelajaran online berbasis teknologi dan 
informasi merupakan media yang berlandaskan pada teknologi dan informasi yang digunakan untuk membantu guru dalam menyampaikan materi dan membantu siswa memahami materi lebih mendalam.

Rusyfian (2016:6) berpendapat bahwa media pembelajaran online berbasis aplikasi Prezi adalah sebuah perangkat lunak untuk presentasi berbasis internet (SaaS). Selain untuk presentasi, aplikasi Prezi juga dapat digunakan sebagai alat untuk mengeksplorasi dan berbagai ide di atas kanvas virtual. Aplikasi Prezi menjadi unggul karena program ini menggunakan en:Zooming User Interface (ZUI), yang memungkinkan pengguna prezi untuk memperbesar dan memperkecil tampilan media presentasi mereka.

Aplikasi Prezi digunakan sebagai alat untuk membuat presentasi dalam bentuk linier maupun nonlinier, yaitu presentasi terstruktur sebagai contoh dari presentasi linier, atau presentasi berbentuk peta pikiran (mindmap) sebagai contoh dari presentasi nonlinier. Pada aplikasi Prezi, teks, gambar, video, dan media presentasi lainnya ditempatkan di atas kanvas presentasi dan dapat dikelompokkan ke dalam bingkai-bingkai yang telah disediakan.

\section{METODE}

Metode yang digunakan dalam penelitian ini adalah metode penelitian dan pengembangan. Jenis data yang akan dihasilkan berupa data kuantitatif. Data kualitatif didapatkan dari angket subjek uji coba. Data kuantitatif didapatkan dari ahli materi, ahli media, dan ahli pendidikan melalui uji coba, sedangkan dari siswa melalui uji kelompok kecil, uji kelompok besar, dan evaluasi. Data yang diperoleh dari validator merupakan data kelayakan materi atau isi, kelayakan tampilan, dan pemrogaman media pembelajaran (Sugiono, 2011:297).

\section{HASIL DAN PEMBAHASAN}

Tahapan pengembangan dari model prosedural menurut Borg dan Gall (dalam Tegeh, 2014:7) diawali dengan analisis kebutuhan. Pada tahap ini penulis menganalisis siswa, lingkungan sekolah, serta yang melatarbelakangi dilaksanakannya penelitian ini. Hal ini dilakukan agar diperoleh data yang dapat mendukung untuk mendesain media berbasis aplikasi Prezi sesuai dengan karakteristik siswa. Tahap analisis kebutuhan diperlukan untuk mendapatkan definisi permasalahan dan gambaran dari apa yang akan dilakukan oleh sebuah model, media dan sumber belajar.

Tahap kedua, penulis membuat desain produk dan pembuatan produk berupa media pembelajaran menulis teks negosiasi dilakukan dengan langkah-langkah, yaitu (a) pembuatan garis besar isi program media (GBIPM) yang di dalamnya terdapat identitas sasaran dan materi seperti kelas yang akan diberikan media, materi, KD, indikator, tujuan pembelajaran, (b) pembuatan flowchat yang berisi alur program yang dibuat urut mulai dari intro pembuka sampai keluar program, (c) pembuatan storyboard yang berisi visualisasi ide dari aplikasi multimedia yang akan dbuat sehingga dapat memberikan gambaran dari aplikasi yang akan dihasilkan. Storyboard dibuat setelah pembuatan flowchart, (d) pengumpulan bahan-bahan berisi pengumpulan bahan atau komponen-komponen yang diperlukan untuk melengkapi media pembelajaran, seperti buku, video, animasi, gambar, musik, (e) pemrogramman berisi proses pembuatan media pembelajaran tersebut yang dimulai dari membuka lembar kerja (kanvas), pemilihan tema, diikuti dengan memberikan zoom pada tampilan yang diinginkan, lalu disusul dengan menyisipkan gambar, musik pada background, dan video atau bagian ini berisi penggabungan semua program yang ada sesuai dengan storyboard, 
(f) finishing berisi kegiatan terakhir atau evaluasi dalam bentuk review dan uji keterbacaan program sesuai dengan target yang diharapkan. Evaluasi bertujuan untuk mengetahui kekuatan dan kelemahan dari media pembelajaran yang telah dikembangkan sekaligus menjadi petunjuk pada penulis tentang bagian-bagain yang akan diperbaiki kembali.

Selanjutnya, uji coba produk tahap 1 dan revisi pertama terhadap hasil desain pengembangan media pembelajaran. Validasi ini dilakukan oleh validator yang terbagi menjadi tiga, yaitu validasi oleh ahli materi, ahli media, dan ahli pendidikan atau pembelajaran. Adapun hasil validasi dari ahli materi tahap I sebesar $87 \%$ dengan kategori baik. Hasil validasi dari ahli media pada aspek tampilan sebesar $54 \%$ dengan kategori kurang layak dan aspek pemrograman sebesar $65 \%$ dengan kategori cukup layak. Hasil validasi dari ahli pendidikan sebesar 85\% dengan kategori baik.

Hasil uji coba produk tahap pertama berupa penilaian, saran, kritik terkait dengan media pembelajaran yang telah direvisi. Selanjutnya, penulis melakukan uji coba terbatas (uji kelompok kecil). Uji coba terbatas ini dilakukan pada kelas X SMA Negeri 1 Anggana, Jurusan IPA (empat kelas) dan IPS (tiga kelas). Setiap populasi dari kelas-kelas tersebut diambil satu orang yang dianggap dapat mewakili dari sejumlah populasi di kelas tersebut. Adapun hasil validasi dari uji coba kelompok terbatas untuk aspek tampilan sebesar 70\% dengan kategori cukup layak, aspek penyajian materi sebesar $75 \%$ dengan kategori cukup layak, dan interaksi program multimedia sebesar $73 \%$ dengan kategori cukup layak.

Setelah melakukan revisi yang kedua dari uji coba terbatas atau uji kelompok kecil, untuk lebih mendapatkan produk yang ideal dilakukan validasi dari validator yang kedua kalinya, yang dilanjutkan dengan revisi ketiga berdasarkan kelemahan atau kekurangan yang dikemukakan oleh validator. Adapun hasil validasi dari validator tahap II, yaitu dari ahli materi sebesar 90\% dengan kategori sangat layak. Hasil validasi dari ahli media pada aspek tampilan sebesar $84 \%$. Aspek pemrograman sebesar $85 \%$ sehingga jika dibuat rata-rata hasil uji ahli media tahap kedua mempunyai nilai $84 \%+85 \% / 2=77 \%$. Angka tersebut berdasarkan tabel interpretasi data termasuk kriteria baik. Hasil validasi dari ahli pendidikan sebesar 91\% dengan kategori sangat layak. Hasil validasi dari ketiga validator tersebut dapat langsung digunakan tanpa melalui tahapan revisi lanjutan.

Hasil validasi dari validator untuk yang kedua kalinya dilanjutkan dengan melakukan uji coba lapangan (kelompok besar). Uji coba ini melibatkan subjek dalam jumlah yang lebih banyak. Uji ini melibatkan seluruh siswa kelas X SMA Negeri 1 Anggana , Jurusan IPA (empat kelas) dan IPS (tiga kelas). Setiap populasi dari kelas-kelas tersebut diambil tiga orang yang dianggap dapat mewakili dari sejumlah populasi di kelas tersebut. Jadi, total 21 responden atau siswa. Adapun hasil validasi dari uji coba kelompok besar untuk aspek tampilan sebesar $89 \%$ dengan kategori sangat layak. Aspek penyajian materi sebesar $91 \%$ dengan kategori sangat layak, dan interaksi program multimedia sebesar 91\% dengan kategori sangat layak. Berdasarkan data hasil uji coba kelompok lapangan (kelompok besar) setelah dilakukan revisi diperoleh nilai persentase rata-rata (rekapitulasi) sebesar 90\% dengan kriteria sangat layak sehingga dapat interpretasikan secara keseluruhan produk pengembangan berupa media pembelajaran ini dapat dapat langsung digunakan tanpa melalui tahapan revisi lanjutan.

Terakhir, tahap ketujuh (tahap evaluasi dan diseminasi) dilakukan verifikasi dan 
validasi ulang sehingga mendapatkan produk pengembangan yang layak dan dapat digunakan sebagai sumber belajar bagi siswa maupun bahan ajar bagi guru. Pada tahap evaluasi ini penulis melakukan tes atau penilaian untuk mengetahui pencapaian kemampuan atau kompetensi kognitif siswa untuk dibandingkan dengan kompetensi awal siswa berupa pretest (sebelum diberikan media) dan posttest (sesudah diberikan media). Selanjutnya, data diolah dengan cara skor setiap siswa dicari selisihnya dengan perhitungan jumlah siswa sebelum menggunakan media dibagi dengan jumlah siswa, yaitu sebesar 53,9. Jumlah siswa setelah menggunakan media dibagi dengan jumlah siswa meningkat menjadi 88,3. Kemudian, dihitung selisih nilai pretest dan posttest dan hasilnya sebesar 34,4 .

Setelah mengetahui kelayakan media pembelajaran tersebut, penulis melakukan diseminasi dengan mendistribusikan produk media pembelajaran tersebut kepada seluruh anggota Musyawarah Guru Mata Pelajaran Bahasa Indonesia (MGMP) dalam bentuk compact disk (CD).

\section{PENUTUP}

Dari hasil penelitian ini dapat disimpulkan beberapa poin sesuai dengan rumusan masalah, yaitu pengembangan media pembelajaran menulis teks negosiasi berbasis aplikasi Prezi pada siswa kelas X SMA Negeri 1 Anggana dikembangkan sesuai dengan tahapan pengembangan dari model prosedural menurut Borg dan Gall. Model penelitian pengembangan ini adalah penelitian yang berorientasi untuk mengembangkan dan memvalidasi produk-produk yang digunakan dalam pendidikan. Dari sepuluh langkah yang dikembangkan oleh Borg and Gall, implementasi dari penelitian ini hanya sampai pada tujuh langkah, yaitu( 1) analisis kebutuhan (latar belakang dilakukannya sebuah penelitian), (2) desain dan pengembangan produk (pembuatan garis besar isi program media (GBIPM), pembuatan flowchat, pembuatan storyboard, pemrograman, dan finishing, (3) validasi produk I (validasi yang dilakukan oleh validator), (4) uji kelompok kecil (Uji coba terbatas yang dilakukan oleh siswa), (5) validasi produk II (validasi yang dilakukan oleh validator), (6) uji kelompok besar (Uji coba lapangan yang dilakukan oleh siswa), dan (7) evaluasi (validasi terakhir yang dilakukan oleh siswa) dan diseminasi (pendistribusian produk), sedangkan pada prinsip media, produk dikembangkan dengan menggunakan aplikasi Prezi.

Berdasarkan penelitian yang telah dilakukan penulis dapat disimpulkan bahwa terjadi perbedaan pada siswa sebelum dan sesudah menggunakan media pembelajaran tersebut. Untuk mengetahui perbedaan yang berdampak pada kelayakan media tersebut, penulis melakukan pretest dan posttest. Hasil pretest serta posttest yang telah dilakukan diketahui bahwa hasil pembelajaran mengalami peningkatan sesudah menggunakan media pembelajaran sebesar $34,4 \%$. Berdasarkan perbedaan hasil belajar tersebut, dapat disimpulkan bahwa media pembelajaran ini layak digunakan dalam proses pembelajaran dalam meningkatkan hasil belajar siswa.

\section{DAFTAR PUSTAKA}

Sadiman, Arief S, dkk. 2003. Media Pendidikan Pengertian, Pengembangan, dan Pemanfaatannya. Jakarta: Raja Grafindo Persada.

Arsyad, Azhar. 2015. Media Pembelajaran. Jakarta: Raja Grafindo.

Kusnadi, Cecep dan Bambang Sutjipto. 2011. Media Pembelajaran Manual dan Digital. Bogor: Ghalia Indonesia.

Daryanto. 2011. Media Pembelajaran. Yogyakarta: Gave Media. 
Kosasih, E. 2014. Jenis-Jenis Teks Dalam Mata Pelajaran Bahasa Indonesia SMA/MA/ SMK. Bandung: Yrama Widya.

Rusyfian, Zurrahma. 2016. Prezi Solusi Presentasi Masa Kini untuk Pelajar, Mahasiswa, dan Pebisnis. Bandung: Informatika.

Sugiyono. 2011. Metode Penelitian Kuantitatif Kualitatif dan RED. Bandung: Alfabeta.

Susilana, Rudi dan Cepi Riyana. 2007. Media Pembelajaran. Bandung: Wacana Prima.

Tegeh, I Made, dkk. 2014. Model Penelitian Pengembangan. Yogyakarta: Graha Ilmu.

Tim Studi Edukasi. 2014. Bahasa Indonesia: untuk SMA-MA/SMK Kelas X. Bandung: Yrama Widya. 